\title{
Enhanced Biosynthesis of Quercetin Occurs as A Photoprotective Measure in Lycopersicon esculentum Mill. under Acute UV-B Exposure
}

\author{
Abhilasha Shourie ", Pushpa Tomar, Deepika Srivastava and Rahul Chauhan \\ Department of Biotechnology; Faculty of Engineering \& Technology; Manav Rachna International Universtiy; \\ Faridabad - India
}

\begin{abstract}
Lycopersicon esculentum respond to $U V-B$ by enhanced synthesis of flavonoid quercetin, a strong antioxidant that helps the plants to well acclimatize to $U V$-B stress. Three weeks old plants of L. esculentum were subjected to acute $U V$-B irradiation for 20, 40 and 60 minutes daily until 28 days and analyzed for the morphological and biochemical changes. UV-B exposure for 40 and 60 minutes considerably affected the growth and biomass of L. esculentum. The leaves were deformed, developed chlorosis and abscised early as compared to the unexposed plants. Biomass declined by $35 \%$ and total chlorophyll decreased by $24.7 \%$ due to disintegration of chloroplasts. Enhancement was seen in the content of carotenoids, anthocyanins and total flavonoids by 15, 33.3 and 22.8\%, respectively, which was attributed to the photoprotective role of these compounds as potential quenchers of excess excitation energy. Quercetin content decreased on UV-B exposure to 20 and $40 \mathrm{~min}$, and thereafter increased significantly by $5.19 \%$ on 60 min of exposure. This pattern probably indicated that the over-expression of genes involved in its biosynthesis such as phenylalanine ammonia lyase (PAL), chalcone synthase (CHS), flavanone 3-hydroxylase (F3H) and dihydroflavonol 4-reductase (DFR) occurred only after certain threshold exposure (60 min), which could be the strategy for developing tolerance against $U V$-B stress in L. esculentum.
\end{abstract}

Key words: UV-B, Lycopersicon esculentum, quercetin, biomass, pigments, anthocyanins

\section{INTRODUCTION}

UV radiations $(200-400 \mathrm{~nm})$ constitute about $7 \%$ of the spectrum of sunlight reaching the earth's surface of which UV-B (280-320 nm), which represent only approximately $1.5 \%$ of the total spectrum, causes the most severe damage to the plants. Interactions with these radiations elicit a variety of morphological, physiological and molecular responses in the plants and bring about many changes such as alter the leaf morphology (Cassi-Lit et al. 1997 and Caldwell et al. 2003), affect photosynthesis and transpiration (Teramura and Sullivan 1994; Maxwell et al. 1999; Cascio et al. 2010), induce changes in plant foliar chemistry (Tevini and Teramura 1989; Teramura et al. 1994), cause DNA and cellular damage, increase susceptibility to diseases, and consequently alter the pattern of plant growth and development directly affecting the yield and nutritional quality of crop plants.

The ability of plants to respond to strong irradiation by the synthesis and accumulation of the compounds selectively absorbing in the UV or the visible part of the spectrum is the foundation of photoprotective mechanisms. Continuous exposure to UV-B potentially damages the photosynthetic system by photobleaching and photodegradation of

*Author for correspondence: aashourie@gmail.com 
pigments (Strid and Porra 1992; Ziska et al. 1993). UV-B irradiation has been reported to decrease the activity of PS II complex with a corresponding decrease in electron transport and ATP synthesis (Campbell et al. 1998), leading to oxidative stress. Such damages are prevented to some extent by accessory pigments such as carotenoids, xanthophylls, anthocyanins, etc. Carotenoids contain seven or more conjugated double bonds and have remarkable capability to quench the triplet sensitizers such as ${ }^{3} \mathrm{chl}$ and the free radical intermediates such as ${ }^{1} \mathrm{O}_{2}$.

UV stress also leads to a cascade of reactions that ultimately result in the formation and accumulation of secondary metabolites (Wilson et al. 2001), which help the plants to acclimatize to UV-B stress. These compounds are mostly phenolics, e.g., anthocyanins and other flavonoids, which show effective absorption in the UV spectral region and are said to be induced on exposure to UV (Lee and Lowry 1980; Reuber et al. 1996; Jenkins et al. 2009 and Stracke et al. 2010). There are several reports focused on the accumulation of flavonoids, including anthocyanins under enhanced UV-B levels, acting as UV-B screens by serving as active oxygen scavengers (Liu et al. 1995; Grace 1998; Hoque and Remus 1999; Burchard et al. 2000). They participate in the elimination of free radicals, thereby strongly combating the oxidative damage (Jenkinset al. 2009). Phenolic synthesis has been shown to be up-regulated by stress-induced oxidative load, while photosynthetic processes are concomitantly said to be down-regulated (Casati and Walbot 2003; Ulm et al. 2004). Pigments and antioxidants, therefore, constitute important line of defense in the plants.

Flavonoids are the most ubiquitous group of natural polyphenols known for their photoprotective and antioxidative role in stress acclimation of the plants, especially as UV filters (Landry and Chapple 1995). Flavonol quercetin is a remarkable scavenger of reactive oxygen species due to its structural properties. It is a potential radical target at an o-dihydroxy group in the B ring, has capacity to delocalize the uncoupled electron of the flavonoid radical due to a double bond between positions 2 and 3 of the C-ring conjugated with keto group in position 4 and is a potential free radical scavenger due to $\mathrm{C}-3, \mathrm{C}-5$ and $\mathrm{C}-7$ hydroxyl groups of the $\mathrm{C}$ and $\mathrm{A}$ rings (Fig. 1) (Strandjord et al.1983; Falkovskaia et al.1998). The double bonds and hydroxyl groups in quercetin donate electrons through resonance to stabilize the free radicals (Smith and Markham 1998; Michalak et al. 2006). The UV energy absorbed by quercetin may be dissipated as heat or converted into decomposition products.

The present work aimed to study the effect of UVB stress on the biosynthesis of major flavonoid quercetin, plant pigments and other phenolics as well as to assess their photoprotective role in the alleviation of stress in Lycopersicon esculentum under acute exposure to UV-B.<smiles>O=c1c(O)c(-c2ccc(O)c(O)c2)oc2cc(O)cc(O)c12</smiles>

Figure 1 - Structure of Quercetin.

\section{MATERIALS AND METHODS}

\section{Plant material and UV-B exposure}

The seeds of L. esculentum Mill (variety Pusa Rohini) were collected from the National Seed Centre, IARI, Pusa, New Delhi. They were germinated in the trays on moist filter paper beds. On fifth day, uniformly germinated seeds were transferred to soil under controlled environmental conditions at $25 \pm 2^{\circ} \mathrm{C}$ and $78 \%$ relative humidity in green house. Twenty-one day old plantlets were exposed to ultraviolet irradiation using UV lamps (302 nm, 20 Watts). The plants were placed at about $30 \mathrm{~cm}$ distance from the lamp to adjust the radiation intensity of $5600 \mu \mathrm{W} / \mathrm{cm}^{2}$. The experimental sets were divided into four batches, having 50 plants each. One set served as control and was left unexposed to UV-B, while other three batches were exposed daily for 28 days to UV-B for different intervals of time, i.e., 20, 40 and 60 minutes, respectively. The light, temperature and humidity regimes were same for the control as well as UV-B exposed plants of L. esculentum. All the biochemical analyses were performed using the plant tissue harvested after 28 days of UV-B exposure.

\section{Growth Parameters}

Plants were visually assessed daily for the shoot and root growth, morphological symptoms in aerial parts, abscission of leaves and senescence. 
Assessment of the biomass was done every seven days throughout the exposure time and biomass was expressed as gram dry weight (gdw) per plant taking average weight of randomly selected 10 plants from each treatment batch.

\section{Determination of Photosynthetic Pigments}

Analysis of chlorophyll a, chlorophyll b and total chlorophyll was done following the method of Arnon (1949). The chlorophyll from $1.0 \mathrm{~g}$ fresh leaf tissue was extracted in $80 \%$ acetone and the absorbance of the extracts at $663 \mathrm{~nm}$ and $645 \mathrm{~nm}$ were measured with a spectrophotometer. The concentrations of chlorophyll a (Chl-a), chlorophyll b (Chl-b), and total chlorophyll were then calculated using the equations (1), (2) and (3), and expressed in $\mu \mathrm{g}$ per gram fresh weight $(\mu \mathrm{g} / \mathrm{gfw})$

Chl-a $=12.72\left(\mathrm{~A}_{663}\right)-2.69\left(\mathrm{~A}_{645}\right)$

Chl-b $=22.9\left(\mathrm{~A}_{645}\right)-4.68\left(\mathrm{~A}_{663}\right)$

Total $\mathrm{Chl}=20.2\left(\mathrm{~A}_{645}\right)+8.02\left(\mathrm{~A}_{663}\right)$

The carotenoid content was determined according to the method of Britton (2005). The dried leaf tissue $(0.5 \mathrm{~g})$ was homogenized with $25 \mathrm{~mL}$ of $95 \%$ ethanol, then $2.0 \mathrm{~mL}$ of $5 \% \mathrm{KOH}$ was added and stored in dark for $2 \mathrm{~h}$. Carotenoids were then extracted using $5.0 \mathrm{~mL}$ of ether and extraction was repeated three times. The supernatant was pooled and absorbance was read at $436 \mathrm{~nm}$ with a spectrophotometer. The total amount of carotenoid was calculated according to the equation (4) and expressed in $\mu \mathrm{g}$ per gram dry weight $(\mu \mathrm{g} / \mathrm{gdw})$ -

Total Carotenoid $=\left[\left(\mathrm{A}_{436} / 0.25\right)\right.$ vol. of ether extract] / initial weight of sample

\section{Determination of Anthocyanins}

Anthocyanins were extracted according to the method of Mazza et al. (2004), for which $1.0 \mathrm{~g}$ of dried plant tissue from each sample was ground in $3.0 \mathrm{~mL}$ acidified methanol $(99: 1$, methanol: $\mathrm{HCl})$ and refluxed for $2 \mathrm{~h}$. Samples were then centrifuged at $17.000 \mathrm{x} \mathrm{g}$ for $20 \mathrm{~min}$ and evaporated to dryness at $40^{\circ} \mathrm{C}$ and reconstituted in methanol to $50 \mathrm{~mL}$. Total anthocyanins were measured using $\mathrm{pH}$ differential method described by Fuleki and Francis (1968), with minor modifications. One milliliter aliquot of the extract was placed into $25 \mathrm{~mL}$ volumetric flasks, diluted to volume with $\mathrm{pH} 1.0$ and $\mathrm{pH} 4.5$ buffer and mixed. The absorbance of the $\mathrm{pH} 1.0$ and $\mathrm{pH} 4.5$ sample preparations were measured at 510 and 700 $\mathrm{nm}$, respectively. Distilled water was used as the blank. The concentration $(\%, w / w)$ of each anthocyanin in the sample was calculated according to the formula given in equation (5) and expressed as cyanidin-3-glc equivalents:

Absorbance $=\left(\mathrm{A}_{510} \mathrm{~nm} \mathrm{pH} 1.0-\mathrm{A}_{700} \mathrm{~nm} \mathrm{pH} 1.0\right)-$ $\left(\mathrm{A}_{510} \mathrm{~nm} \mathrm{pH} 4.5-\mathrm{A}_{700} \mathrm{~nm} \mathrm{pH}\right.$ 4.5)

The percent weight per weight $(\% \mathrm{w} / \mathrm{w})$ of total anthocyanins in the sample was calculated as given in equation (6):

$\%(\mathrm{w} / \mathrm{w})=(\mathrm{A} / \varepsilon \mathrm{L}) \times \mathrm{MW} \times \mathrm{DF} \times(\mathrm{V} / \mathrm{Wt}) \times 100 \%$ (6)

Where, $\mathrm{A}$ is the absorbance;

$\varepsilon$ is the extinction coefficient $\left(26,900 \mathrm{M}^{-1} \mathrm{~cm}^{-1}\right.$ for cy-3-glc);

MW is the molecular weight $(449.2 \mathrm{~g} / \mathrm{mol}$ for cy3-glc);

$\mathrm{DF}$ is the dilution factor (1 ML sample is diluted to $25 \mathrm{~mL}, \mathrm{DF}=25)$;

$\mathrm{V}$ is the final volume $(50 \mathrm{~mL})$;

$\mathrm{Wt}$ is the sample weight $(1 \mathrm{~g})$;

$\mathrm{L}$ is the cell path length $(1 \mathrm{~cm})$.

\section{Determination of Total Flavonoids}

Aluminium chloride colorimetric method was used to determine flavonoid content in the aerial parts of the plants (Harborne 1973; Aiyegroro and Okoh 2010). Flavonoids were extracted in acidified methanol (methanol: water: $\mathrm{HCl}, 78: 20: 2, \mathrm{v} / \mathrm{v}$ ) at $4^{\circ} \mathrm{C}$ for $24 \mathrm{~h}$. Aliquots of $1.0 \mathrm{~mL}$ from each extract was mixed with $3.0 \mathrm{~mL}$ of methanol, $0.2 \mathrm{~mL}$ of $10 \%$ aluminium chloride, $0.2 \mathrm{~mL}$ of $1 \mathrm{M}$ potassium acetate and $5.6 \mathrm{~mL}$ of distilled water. After incubation at room temperature for $30 \mathrm{~min}$, the absorbance of the reaction mixture was measured at $415 \mathrm{~nm}$ with a spectrophotometer. The calibration curve was prepared by using quercetin as standard. Flavonoid contents were determined from the standard curve and were expressed as quercetin equivalents $(\mathrm{mg} / \mathrm{gdw})$.

\section{Determination of Quercetin}

The estimation of quercetin in the samples was done through RP-HPLC. The plant samples were extracted in $80 \%$ ethyl alcohol and then refluxed with $6.0 \mathrm{~mL}$ of $25 \%$ hydrochloric acid for one hour and a weighed amount of each hydrolysate was dissolved in HPLC grade methanol to give a concentration of $100 \mu \mathrm{g} / \mathrm{mL}$. All the samples were stored at $4{ }^{\circ} \mathrm{C}$ and were filtered through a $0.45 \mu \mathrm{m}$ filter before undertaking the HPLC analysis. The 
chromatographic analyses were performed on HPLC system (Agilent Technologies) equipped with 1100 series isocratic pump, manual injector, variable wavelength detector with deuterium lamp, and a reversed-phase pre-packed C18 column (150 x $4.6 \mathrm{~mm}, 5 \mu \mathrm{m}$ particle size). The column was maintained at room temperature. The mobile phase was run at as a flow rate of $1.0 \mathrm{~mL} / \mathrm{min}$ and consisted of acetonitrile/water (1:1), acidified with $1 \%$ acetic acid. Throughout the experiment, all the injection volumes were $10 \mu \mathrm{L}$ and the compounds were detected at $254 \mathrm{~nm}$. Quercetin was identified by direct comparison of retention time of its peak $\left(\mathrm{R}_{\mathrm{t}}=2.76\right)$ with reference standard (Quercetin 98.0\%, CAS No. 6151-25-3, Himedia RM6191) and quantified on the basis of its peak area.

\section{Statistical Analysis}

All the experiments were conducted using three replicates per treatment and data presented as mean \pm standard error (SE). The significant differences between the control and UV-B exposed plants were analyzed by Tukey's post hoc test using one-way ANOVA for comparison of the means at the level of significance $p<0.05$.

\section{RESULTS AND DISCUSSION}

\section{Effects of UV-B exposure on plant morphology and biomass}

Results showed marked difference in the morphology and growth of UV-B irradiated plants as compared to non-irradiated plants of $L$. esculentum. Conspicuous morphological effects were seen after acute exposure to UV-B radiation for 40 and 60 min such as shrunken leaves, shorter plant height and less extensive root system. However, no considerable negative effects were observed on the morphology on lesser exposure to UV-B, i.e., for $20 \mathrm{~min}$. The damage caused to the leaf tissues by UV-B was evident by leaf surface characteristics such as appearance of necrotic spots, burning at the leaf margins and yellowing of leaves caused due to depletion of chlorophyll. Biomass was analyzed in the whole plants at the interval of every seven days. After 28 days, it decreased up to $35 \%$ on exposure to UV-B for 60 min in comparison to the control. There was apparently very less effect on the biomass on lesser exposure to UV-B, i.e., for $20 \mathrm{~min}$ (Fig. 2). Modification of plant morphology and reduction in growth due to UV-B radiation as observed in the present study was in agreement with several researches done on barley (Aiyegroro and Okoh 2010), green gram (Rajendiran and Ramanujam 2004), soybean (Roman et al.1984), lettuce (Krizek et al.1998) and rye (Tevini et al.1991). Lowering of biomass accumulation with respect to increasing UV-B exposure could be related to slower growth and rapid degeneration of leaf tissue over the time. It was deduced that the plants showed tolerance towards the UV stress until a critical exposure limit (in this case $40 \mathrm{~min}$ ) was reached beyond which deleterious effects of radiation stress became quite conspicuous. Biomass production in the plant is directly correlated with growth and yield of plant. It represents total carbon assimilation occurring through the primary metabolism and is, therefore, a good indicator of physiological well-being and growth of the plant.

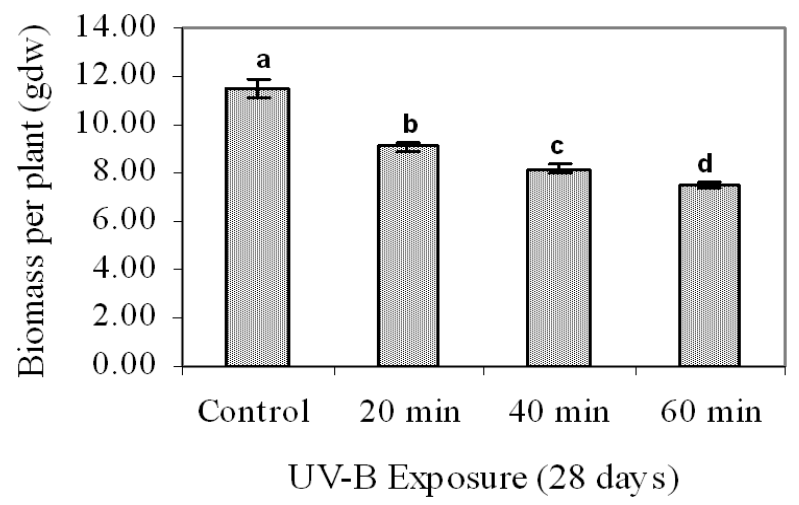

Figure 2 - Effect of UV-B on Biomass of Lycopersicon esculentum. Results expressed as \pm SEM of three determinations. Values marked by same letter are not significantly different $(p<0.05)$ from control and from each other.

Effects of UV-B exposure on photosynthetic pigments- chlorophyll and carotenoids

Chlorophyll contents were affected at all the doses of UV-B, but at the longest duration of exposure (60 $\mathrm{min})$, these declined significantly and total chlorophyll reduced by $24.7 \%$ as compared to untreated plants (Fig. 3). Conversely, carotenoid contents increased in the amounts consistently with UV-B exposure for 20, 40 and $60 \mathrm{~min}(0.95$, 1.02 and $1.07 \mu \mathrm{g} / \mathrm{gdw}$ respectively), and maximum enhancement was about $15 \%$ as compared to untreated samples $(0.91 \mu \mathrm{g} / \mathrm{gdw})$, (Fig. 4). Chlorophyll depletion was in accordance with rapid yellowing and chlorosis observed in case of 
longer exposures to UV-B (60 min), which could be due to several reasons such as excessive photodegradation and depletion of chlorophyll (Strid and Porra 1992), disintegration of chloroplasts (Tevini et al. 1991; Strid and Porra 1992; and Cassi et al. 1997), inhibition of cab gene expression and consequent reduction in the biosynthesis of chlorophyll proteins (Strid and Porra 1992). Chlorophyll a and b are primarily involved in harvesting the light for photosynthesis. Any change in chlorophyll content may lead to impairing of this process, directly affecting carbon assimilation and biomass production (Herrmann et al. 1997; Kakani et al. 2003). Carotenoids are accessory pigments, which help in harvesting of the light and protect chlorophylls from photoxidative destruction by quenching the tripletstate photosensitizers, singlet oxygen and peroxy radicals (Krinsky 1989; Woodall 1997). Carotenoid pigments increase mostly under the conditions where there is less photosynthetic assimilation rate with more UV-B radiation (Campbell et al.1998). The present results were probably indicative of UV-B inducible carotenogenesis (Waterman and Mole 1994), ensuring the photo-protective role of carotenoids in photosynthetic systems by dissipating excess excitation energy.

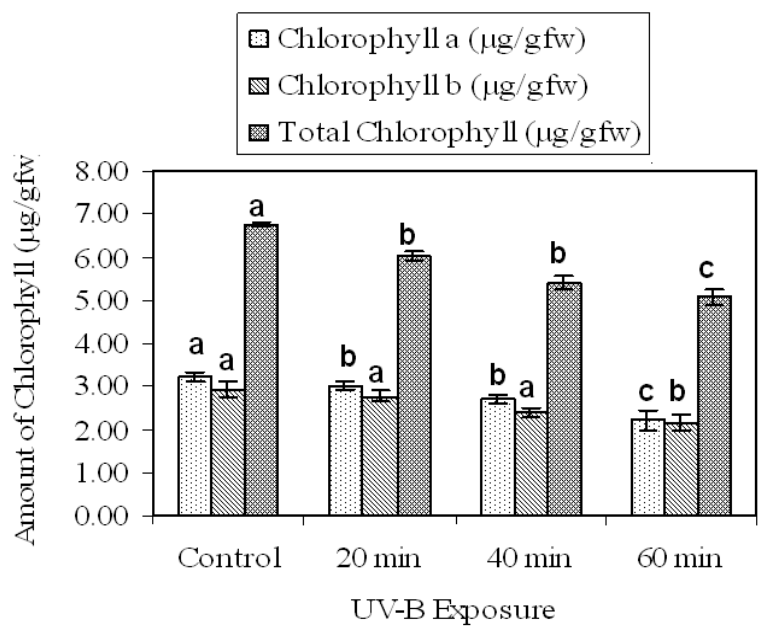

Figure 3 - Effect of UV-B on chlorophyll content of Lycopersicon esculentum. Results expressed as \pm SEM of three determinations. Values marked by same letter are not significantly different $(p<0.05)$ from control and from each other.

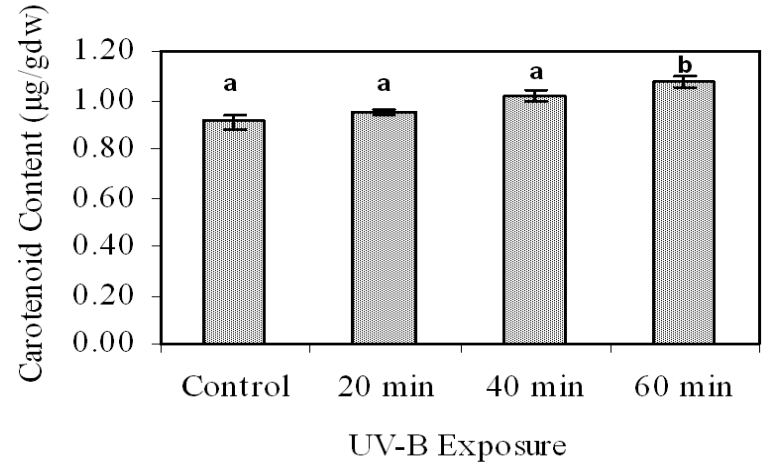

Figure 4- Effect of UV-B on carotenoid content of Lycopersicon esculentum. Results expressed as \pm SEM of three determinations. Values marked by same letter are not significantly different $(p<0.05)$ from control and from each other.

\section{Effects of UV-B exposure on anthocyanin and total flavonoid content}

There was a sharp increase in anthocyanin content on exposure to UV-B for 40 and $60 \mathrm{~min}$, which was about $33.3 \%$ as compared to unexposed plants (Fig. 5). Lesser exposure to UV-B, i.e., for $20 \mathrm{~min}$ was not sufficient to enhance the biosynthesis of anthocyanins. Several studies have hypothesized that anthocyanin provides a "UV sunscreen" and that exposure to ultraviolet (UV) light promotes the production of foliar anthocyanin in the plants (Lee and Lowry 1980; Waterman and Mole 1994; Caldwell et al. 1999; Gould et al. 2000). Accumulation of plant phenolics is directly related to the intensity of solar radiation to which it is exposed (Waterman and Mole 1994; Caldwell et al. 1999). This provides direct evidence of involvement of phenolics such as anthocyanins and other flavonoids in minimizing and overcoming the harmful effects of radiation stress such as cellular damage, oxidative damage and DNA damage (Caldwell et al. 1999).

Total flavonoids also significantly enhanced in UV-B exposed plants of $L$. esculentum and showed sudden increase of $22.8 \%$ at $40 \mathrm{~min}$ of UV-B exposure, and $38 \%$ at $60 \mathrm{~min}$ of UV-B exposure, as compared to control (Fig. 6). Biosynthesis of flavonoids is often induced under the influence of UV-B radiation in the plants ( $\mathrm{Li}$ et al. 1993; Jordan 1996; Caldwell et al. 1999 and Jenkins et al. 2009), which may be due to the increased influx of precursor amino acids into their metabolic pathways. This can be seen as a strategy of the plants to overcome UV-B stress through 
effective absorption shown by the flavonoids in the UV-B spectral region (Reuber et al.1996; Schnitzler et al. 1996 and Hoque and Remus 1999) and by overcoming the oxidative stress in cells (Dawar et al. 1998). Despite these favourable effects in the plants, the increased level of flavonoids has been shown to interfere with vital physiological processes such as ATP synthesis and oxidative phosphorylation leading to disintegration of chloroplasts, causing chlorosis and necrosis (Kumari et al. 2009). In the present study, longer exposure of L. esculentum plants to UV-B induced higher accumulation of flavonoids as a photoptotective mechanism, but simultaneously the destruction of chloroplast led to yellowing and early senescence of the leaves.

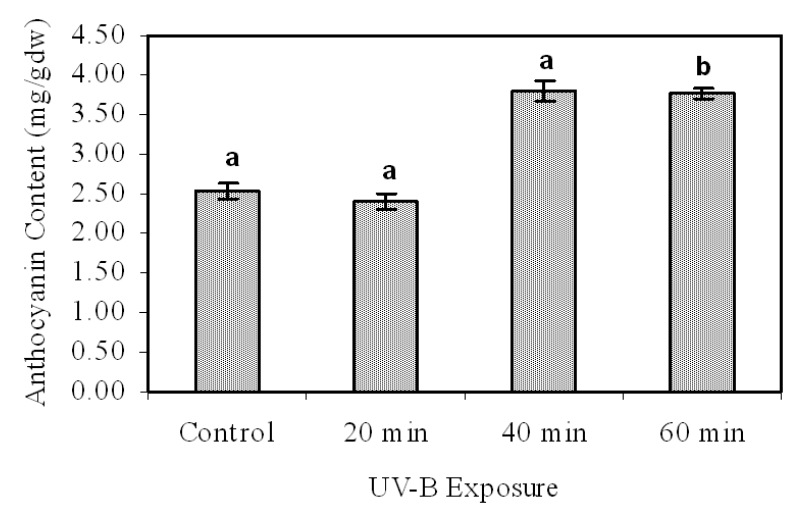

Figure 5- Effect of UV-B on anthocyanins of Lycopersicon esculentum. Results expressed as \pm SEM of three determinations. Values marked by same letter are not significantly different $(p<0.05)$ from control and from each other.

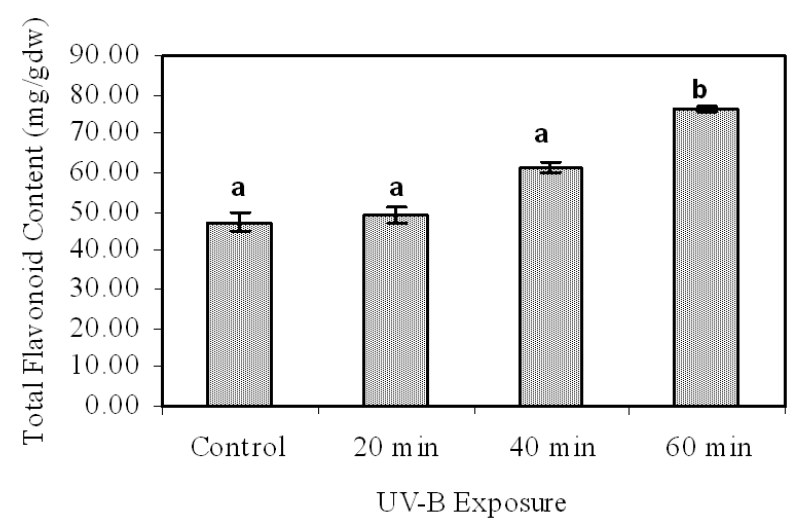

Figure 6- Effect of UV-B on total flavonoid content of Lycopersicon esculentum. Results expressed as \pm SEM of three determinations. Values marked by same letter are not significantly different $(\mathrm{p}<0.05)$ from control and from each other.
Estimation of Quercetin content by RP-HPLC Considerable accumulation of total flavonoids in UV-B exposed plants of $L$. esculentum led to the quantification of quercetin, one of its major flavonoid. It was observed that the amount of quercetin decreased slightly on 20 min of exposure to UV-B $(0.62 \mu \mathrm{g} / \mathrm{gdw})$ as compared to the unexposed ones $(0.73 \mu \mathrm{g} / \mathrm{gdw})$. Thereafter, it increased by $5.19 \%$ on $60 \mathrm{~min}$ of exposure. The increase in quercetin on $40 \mathrm{~min}$ of exposure was insignificant (Fig. 7). Although the absorbance maxima of quercetin lies in the UV-A and UV-C region $\left(\lambda_{\max }=365 \mathrm{~nm}\right.$ and $256 \mathrm{~nm}$ respectively), its photoprotective role in UV-B stressed plants may be attributed to its potential radical scavenging activity, which help to prevent direct DNA damage rather than direct absorption of UV$B$ radiations. Quercetin has a polyphenol structure, which contains numerous double bonds and hydroxyl groups that can donate electrons through resonance (Fig. 1) to stabilize the free radicals (Machlin and Bendich 1987). Quercetin, which absorbs UV radiation at 255 and $365 \mathrm{~nm}$, is determined to be a strong inhibitor of lipid oxidation induced by UV-B (3.7 radicals scavenged per molecule) (Fahlman and Krol 2009).

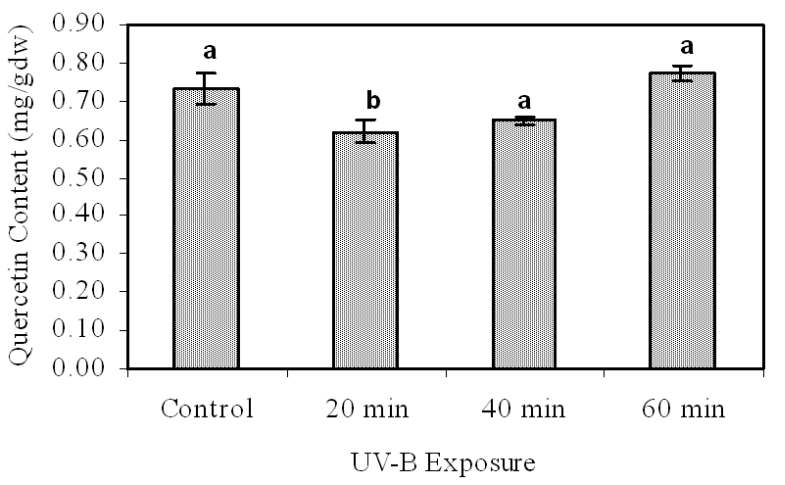

Figure 7- Effect of UV-B on Quercetin in aerial parts of Lycopersicon esculentum. Results expressed as \pm SEM of three determinations. Values marked by same letter are not significantly different $(p<0.05)$ from control and from each other.

There are several reports indicating the accumulation of quercetin under UV-B due to over-expression of flavonoids biosynthesis genes such as Phenylalanine ammonia lyase (PAL), chalcone synthase (CHS), flavanone 3hydroxylase $(\mathrm{F} 3 \mathrm{H})$, dihydroflavonol 4-reductase 
(DFR), and anthocyanidin synthase (ANS) ) (Xu and Li 2006; Zhou et al. 2007). Similar responses have also been reported in Arabidopsis, involving three key factors COP1 (an E3 ubiquitin ligase), UVR8 (a $\beta$-propeller protein), and HY5 (a bZIP transcription factor) mediating the accumulation of quercetin under the sun simulator growth conditions (Henriette et al. 2010). Homologs of these Arabidopsis factors are said to be encoded by the genome of a moss Physcomitrella patens (Richardt et al. 2007; Luise et al. 2010), which are instrumental in conferring the protection and constitute a UV signaling pathway (Jiang et al. 2006 and Luise et al. 2010).

\section{CONCLUSIONS}

Overall, the growth of the L. esculentum retarded by longer UV-B exposures. Along with other morphological deformities, biomass reduced significantly to about $35 \%$, which was a matter of concern regarding crop yield under such stress conditions. However, L. esculentum plants responded to UV showing some beneficial stress interactions such as accumulation of flavonoids, in particular quercetin. It was also observed that the biosynthesis of such photoprotective metabolites was induced only after exposure to certain threshold period of time, which was critical and depended upon the type of radiation, age and physiological state of the plant. Limited exposure to UV-B is said to stimulate such responses, while longer exposure exert high influence, causing cellular damage by generating photoproducts in DNA and directly damaging the proteins. In this study, the biosynthesis of quercetin and other metabolites was sufficiently stimulated on acute UV-B exposure to at least $60 \mathrm{~min}$ daily as accounted for 28 days. Therefore, it could be proposed that the accumulation of quercetin could be used as the biochemical model to examine the underlying strategies of developing UV tolerance in the plants. This could further lead to investigate the potential role of quercetin as a key metabolic marker for UV resistance in the plants and help in selection of UV tolerant crop plants having high content of nutritionally important metabolitequercetin.

\section{REFERENCES}

Aiyegroro OA, Okoh, AI. Preliminary phytochemical screening and in vitro antioxidant activities of aqueous extract of Helichrysum longifolium DC. BMC Compl And Alt Med. 2010; 10: 21.

Arnon DL. A copper enzyme is isolated chloroplast polyphenol oxidase in Beta Vulgaries. Plant Physiol. 1949; 24:1-15.

Britton G. UV/visible spectroscopy. In: G. Britton, S. Liaaen-Jensen, H. Pfander (Eds.), Carotenoids, Vol. 1B Spectroscopy. Birkhäuser Verlag, Basel, Switzerland; 1995.p. 13-62.

Burchard P, Bilger W, Weissenböck G. Contribution of hydroxycinnamates and flavonoids to epidermal shielding of UV-A and UV-B radiation in developing rye primary leaves as measured by ultravioletinduced chlorophyll fluorescence measurements. Plant Cell Environ. 2000; 23:1373-1380.

Caldwell MM, Ballare CL, Bornman JF, Flint SD, Bjorn LO, Teramura AH et al. Terrestrial ecosystems, increased solar ultraviolet radiation and interactions with other climatic change factors. Photochem Photobiol Sci. 2003; 2:29-38.

Caldwell MM, Searles PS, Flint SD, Barnes PW. Terrestrial ecosystem responses to solar UV-B radiation mediated by vegetation, microbes and abiotic phytochemistry. Physiol Plant Ecol. Oxford, Blackwell Science. 1999; 241-262.

Campbell D, Eriksson MO, Quist G, Gustafsson P, Clarke AK. The cyanobacterium Synechococcus resists UV-B by exchanging photosystem II reactioncenter D1 proteins. Plant Biology. 1998; 95: 364-369.

Casati P, Walbot V. Gene expression profile in response to ultraviolet radiation in maize genotypes with varying flavonoid content. Plant Physiol. 2003; 132: 1739-1754.

Cascio CM, Schaub K, Novak R, Desotgiu F, Bussotti, Strasser RJ. Foliar responses to ozone of Fagus sylvatica L. seedlings grown in shaded and in full sunlight conditions. Environ Exp Bot. 2010; 68:188197.

Cassi-Lit MM, Whitecross J, Nayudu M, Tanner GJ. UV-B radiation induces differential leaf damage, ultra structural changes and accumulation of specific phenolic compounds in rice cultivars. Aust J Plant Physiol. 1997; 24: 261-274.

Dawar S, Vani T, Singhal GS. Stimulation of antioxidant enzymes and lipid peroxidation by UV-B irradation in the thylakoid membranes of wheat. Biol Plant. 1998; 41: 65-73.

Fahlman BM, Krol ES. Inhibition of UVA and UVB radiation-induced lipid oxidation by quercetin, $J$ Agric Food Chem. 2009; 57(12): 5301-5305. 
Falkovskaia F, Sengupta PK, Kasha M. Photophysical induction of dual fluorescence of quercetin and related hydroxyflavones upon intermolecular $\mathrm{H}$ bonding to solvent matrix, Chem Phys Lett. 1998; 297: 109-114.

Fulcki $\mathrm{T}$ and Francis FJ. Quantitative method for anthocyanins extraction and determination of total anthocyanin in cranberries, J Food Sci. 1968; 33:7277.

Grace SC, Logan BA, Adams WW III. Seasonal differences in foliar content of chlorogenic acid, a phenylpropanoid antioxidant, in Mahonia repens. Plant Cell Environ . 1998; 21: 513-521.

Greenberg BM, Wilson MI, Huang XD, Duxbury CL, Gerhaddt KE, Gensemer RW. The effects of ultraviolet- B radiation on higher plants. In: Wang W, Gorsuch JW, Hughes $\mathrm{J}$ editors. Plants for environmental studies. Boca Raton, Florida, CRC Press. 1997; 1-35.

Harborne JB. Phytochemical Methods, Chapman and Hall Ltd., London. 1973; 49-188.

He J, Huang LK, Whitecross MI. Chloroplast ultrastructure changes in Pisum sativum associated with supplementary ultraviolet (UV-B) radiation. Plant Cell Envir. 1994; 17: 771-775.

Hectors K, Prinsen E, Coen WD, JansenMAK, Guisez Y. Arabidopsis thaliana plants acclimated to low dose rates of ultraviolet $B$ radiation show specific changes in morphology and gene expression in the absence of stress symptoms. New Phytol. 2007; 175: 255-270.

Henriette G, Marc H, Werner H, Andreas A, Harald KS and Roman Ulm. Negative feedback regulation of UV-B-induced photomorphogenesis and stress acclimation in Arabidopsis. Plant Biology. 2010; 107 (46): 20132-20137.

Herrmann H, Hader DP, Ghetti F. Inhibition of photosynthesis by solar radiation in Dunaliella salina: Relative efficiencies of UV-B, UV-A and PAR. Plant Cell Environ. 1997; 20: 359-365.

Hoque E, Remus G. Natural UV-screening mechanisms of Norway spruce (Picea abies L. Karst) needles. Photochem Photobiol. 1999; 69:177-192.

Jenkins GI. Signal transduction in responses to UV-B radiation. Annu Rev Plant Biol. 2009; 60:407-431.

Jiang C, Schommer CK, Kim SY, Suh DY. Cloning and characterization of chalcone synthase from the moss Physcomitrella patens. Phytochemistry. 2006; 67: 2531-2540.

John De Britto A, Jeevitha M, Leon Stephan Raj T. Alterations of protein and DNA profiles of Zea mays L. under UV- B radiation. J Stress Physiol Biochem. 2011; 7(4): 232-240.

Jordan BR. The effects of ultraviolet-B radiation on plants: a molecular perspective. Adv Bot Res. 1996; 22: 98-162.
Kakani VG, Reddy KR, Zhao D and Sailaja K. Field crop responses to ultraviolet-B radiation: A review. Agric For Meteorol. 2003; 120: 191-218.

Krinsky NI. Antioxidant function of carotenoids. Free Radical Biol Med. 1989; 7: 617-635.

Krizek DT, Brita SJ, and Miewcki RM. Inhibitory effects of ambient level of solar UV-A and UV-B on growth of cv. New Red Fire lettuce, Physiol Plant. 1998; 103: 1- 7.

Kumari R, Singh S, Agrawal SB. Effects of supplemental UV-B radiation on growth and physiology of Acorus calamus L. (Sweet flag). Acta Biol Crac Ser Bot. 2009; 51: 19-27.

Landry LG, Chapple CGS, Last RL. Arabidopsis mutants lacking phenolics sunscreens exhibit enhanced ultraviolet-B injury and oxidative damage. Plant Physiol. 1995; 109:1159-1166.

Lee DW, Lowry JB, Young-leaf anthocyanin and solar ultraviolet. Biotropica. 1980; 127: 75-76.

Li J, Ou-Lee T, Raba R, Amudson R, Last R. Arabidopsis flavonoid mutants are hypersensitive to UV-B irradiation. Plant Cell. 1993; 5: 171-179.

Liu L, Gitz DC, III McClure JW. Effects of UV-B on flavonoids, ferulic acid, growth and photosynthesis in barley primary leaves. Physiol Plant. 1995; 93: 725733.

Wolf L, Rizzini L, Stracke R, Ulm R, Rensing SA. The Molecular and Physiological Responses of Physcomitrella patens to Ultraviolet-B Radiation. Plant Physiol. 2010; 153(3): 1123-1134.

Maxwell K, Marrison JL, Leech RM, Griffiths H, Horton P. Chloroplast acclimation in leaves of Guzmania monostachia in response to high light. Plant Physiol. 1999; 121: 89-96.

Mazza CA, Battista D, Zima AM, SzwarcbergBracchitta M, Giordano CV, Acevedo A,et al. The effects of solar ultraviolet-B radiation on the growth and yield of barley are accompanied by increased DNA damage and antioxidant responses. Plant Cell Environ. 1999; 22: 61-70.

Mazza G, Cacace JE, Kay CD. Methods of analysis for anthocyanins in plants and biological fluids. $J$. AOACInternat. 2004; 87(1):129-145.

Michalak A. Phenolic compounds and their antioxidant activity in plants growing under heavy metal stress. Polish J of Environ Stud. 2006; 15(4): 523-530.

Rajendiran K, Ramanujam MP. Improvement of biomass partitioning, flowering and yield by triadimefon in UV-B stressed Vigna radiata (L.) Wilczek. Bio Plant. 2004; 48(1):145-148.

Reuber S, Bornman JF, Weissenbock G. A flavonoid mutant of barley (Hordeum vulgare L.) exhibits increased sensitivity to UV-B radiation in the primary leaf. Plant Cell Environ. 1996; 19: 593-601. 
Richardt S, Lang D, Frank W, Reski R, Rensing SA. PlanTAPDB: A phylogeny-based resource of plant transcription associated proteins. Plant Physiol. 2007; 143: 1452-1466.

Roman MM, Alan HT. Effects of ultraviolet-B irradiance on soybean -The dependence of plant sensitivity on the photosynthetic photon flux density during and after leaf expansion. Plant Physiol. 1984; 74(3):475-480.

Schnitzler JP, Jungblut TP, Heller W, Köfferlein M, Hutzler P, Heinzmann U, et al. Tissue localization of UV-B-screening pigments and of chalcone synthase mRNA in needles of scots pine seedlings. New Phytol. 1996; 132: 247-258.

Smith GJ, Markham KR. Tautomerism of flavonol glucosides - relevance to plant UV protection and flower colour. J.Photochem. Photobiol A Chem. 1998; 118: 99-105.

Stracke R, Favory JJ, Gruber H, Bartelniewoehner L, Bartels S, BinkertM, et al. The Arabidopsis bZIP transcription factor HY5 regulates expression of the PFG1/MYB12 gene in response to light and ultraviolet-B radiation. Plant Cell Environ. 2010; 33: 88-103.

Strandjord AJG, Courtney SH, Friedrich DM, Barbara PF. Excited state dynamics of 3-hydroxyflavone, $J$ Phys Chem. 1983; 87:1125-1133.

Strid A and Porra RJ. Alterations in pigment content in leaves of Pisum sativum after exposure to supplementary UV-B. Plant Cell Physiol. 1992; 331: 1015-1023.

Teramura AH, and Sullivan JH. Effect of UV-B radiation on photosynthesis and growth of terrestrial plants. Photosynth. Res. 1994; 394:63-473.

Tevini M, Braun J, and Fieser G. The protective function of the epidermal layer of rye seedlings against ultraviolet- B radiation. Photochem Photobiol. 1991; 533: 29-333.

Tevini M, Mark U, Saile-Mark M. Effects of enhanced solar UV-B radiation on growth and function of crop plant seedlings. Curr. Top. Plant Biochem Physiol. $1991 ; 10: 13-31$.
Tevini M, Teramura AH. UV-B effects on terrestrial plants. Photochem Photobiol. 1989; 504: 479-487.

Ulm R, Baumann A, Oravecz A, Mate Z, Adam E, Oakeley EJ, Schafer E, Nagy F. Genome-wide analysis of gene expression reveals function of the bZIP transcription factor HY5 in the UV-B response of Arabidopsis. Proc Natl Acad Sci USA. 2004; 101: 1397-1402.

Waterman PG, Mole S. Methods in Ecology. Analysis of phenolic plant metabolites. Blackwell Sci Publ., London. 1994; 66-103.

Wilson KE, Thompson JE, Huner NP, Greenberg BM. Effects of ultraviolet-A exposure on ultraviolet-B induced accumulation of specific flavonoids in Brassica napus. Photochem Photobiol. 2001; 73: 678-684.

Woodall AA, Britton G, Jackson MJ. Carotenoids and protection of phospholipids in solution or liposomes against oxidation by peroxyl radicals: relationship between carotenoid structure and protective ability. Biochem Biophys Acta. 1997; 1336: 575-586.

Woodall AA, Britton G, Jackson MJ. Carotenoids and protection of phospholipids in solution or liposomes against oxidation by peroxyl radicals: relationship between carotenoid structure and protective ability. Biochem Biophys Acta. 1997; 1336: 575-586.

$\mathrm{Xu}$ ZR, Li YH. Screening the genes associated with anthocyanin biosynthesis in roots of 'Tsuda' turnip using cDNA microarray. Hereditas. 2006; 28(9): 1101-1106.

Zhou B, Li Y, Xu Z, Yan H, Homma S, Kawabta S. Ultraviolet A specific induction of anthocyanin biosynthesis in the swollen hypocotyls of turnip (Brassica rapa). J Exp Bot. 2007; 58: 1771-1781.

Ziska LH, Teramura AH, Sullivan JH, Mccoy A. Influence of ultraviolet-B radiation on photosynthetic and growth characteristics in field grown cassava (Manihot esculentum Crantz). Plant Cell Environ. 1993; 16:73-79. 